\title{
Nilai Waktu dalam Ungkapan Tradisional Bugis di Lombok: Sebuah Kajian Bahasa dan Budaya
}

\author{
Syarifuddin*)
}

\begin{abstract}
Bugies is one of ethnic that have lived nomad. They can be finding at any coastal area in Indonesia, and one of them is in Lombok Island. To holding out and succeed live in the foreign, the bugisnes must be apreciate times. The times reflection of traditional expression such as fore fathers advice and papaseng. The papaseng indicates that the times are always changes. A change of times can be happens such as change of an actor, activities, or something in real life. Then, one of positive thing that always do in Bugiesness real life is appriciate the times.The values which are consists in it always be guide for whole Bugisnes to realizing wishes in their real life.
\end{abstract}

Key words: language, culture values, value times

\section{Pengantar}

Bahasa Bugis, sama seperti bahasa-bahasa daerah lainnya yang ada di Indonesia digunakan sebagai pengawet budaya. Pengawet budaya melalui bahasanya merujuk pada pengomunikasian unsur-unsur budaya. Hal itu terbukti dari kegiatan adat-istiadat pada sebagian besar etnis di Indonesia tetap menggunakan bahasanya sendiri. Fenomena itu masih ditemukan pada masyarakat Bugis baik yang masih tinggal di daerah tanah asalnya (tana ugi) maupun yang telah tinggal di luar wilayah itu, salah satunya di Pulau Lombok. Masyarakat Bugis sebagai etnis pendatang di wilayah Pulau Lombok tersebut selalu berkontaminasi dengan etnis pribumi (Sasak) atau antaretnis pendatang lainnya (Jawa, Bali, Sumbawa, dan Bajo) yang hidup berdampingan dengannya. Dalam memperlancar komunikasi tersebut, dituntut penggunaan bahasa

\footnotetext{
*) Doktor Ilmu Linguistik, Pembantu Pimpinan pada Kantor Bahasa Provinsi NTB
} 
Indonesia atau mungkin bahasa pribumi yang paling dominan digunakan di tempat mereka menetap sekarang. Secara nirsadar kosakata dari budaya baru yang sebelumnya tidak ada di lingkungan budaya mereka akan masuk dan digunakan dalam bahasa dan budayanya. Oleh karena itu, kosakata baru bagi masyarakat Bugis cenderung diserap melalui bahasa Indonesia dan pribumi. Namun, sebagian besar lafalnya disesuaikan dengan lingkungan fonetik bahasa Bugis.

Walaupun perkembangan bahasa itu bersifat dinamis, namun ada unsur bahasa yang cenderung baku dan beku baik dari segi struktur maupun makna (maksud), salah satunya adalah ungkapan (bdk. Djajasudarma et al, 1997). Secara universal, ungkapan itu dibangun oleh satuan-satuan bahasa dengan bentuk-bentuk baku dan beku. Unsur-unsur tersebut diwariskan secara turun-temurun dengan struktur dan makna yang sama meskipun sebagian makna ekspresi itu tidak cocok bagi budaya masa tertentu. Lain halnya dengan ungkapan tradisional Bugis di wilayah Pulau Lombok yang berupa nasehat-nasehat leluhur, yang mereka sebut dengan istilah pappaseng (istilah tersebut, selanjutnya akan digunakan di sepanjang tulisan ini) masih tetap dipertahankan bentuk dan makna yang terkandung di dalamnya. Hal ini dapat dikatakan bahwa ungkapan tradisional Bugis tersebut menggambarkan prinsip yang dianut dari generasi ke genarasi.

Ungkapan tradisional merupakan unsur bahasa yang dapat menggambarkan budaya suatu masyarakat bahasa pada zamannya atau unsur-unsur budaya yang memiliki nilai yang sebagian besar menjadi pedoman atau larangan dalam aktivitas manusia berbudaya (bdk. Djajasudarma at al, 1997). Hasil kegiatan manusia dalam hubungannya dengan kehidupan, karya, waktu, alam, dan manusia itu sendiri dapat dipahami sebagai budaya (Koentjaraningrat, 1974). Sehubungan dengan 
itu, nilai-nilai budaya dalam tulisan ini dipahami sebagai hasil aktivitas manusia yang digambarkan melalui pappaseng yang menjadi prinsip pedoman bertingkah laku dalam melaksanakan kegiatan yang berhubungan dengan orientasi nilai budaya (kehidupan, karya, waktu, alam, manusia) (lihat Kluckhon dalam Kuntjaraningrat, 1974: 23-37).

Hasil kegiatan (aktivitas) manusia yang merupakan nilai budaya yang ditelusuri dalam pappaseng tersebut dapat menggambarkan aktivitas yang berupa anjuran-larangan, atau pedoman untuk bertindak yang patut dipertahankan karena bermanfaat positif dalam menentukan sikap hidup (bdk. Djajasudarma et al, 1997). Apabila berpatokan pada nilai sebagai segala sesuatu tentang yang baik dan yang buruk (Pepper, 1958) maka nilai menyangkut yang baik itu patut dipedomani dalam bertingkah laku, yang buruk itu yang tidak dipedomani dalam bertingkah laku. Pedoman dalam bertingkah laku inilah yang selalu diperhatikan oleh masyarakat Bugis di Pulau Lombok dalam mempertahankan dirinya di tengah hegemoni masyarakat pribumi, di samping ditemukan juga nilai budaya yang generik, berlaku umum, atau tidak menyangkut pedoman yang baik atau buruk. Dengan kata lain, dalam penelitian ini, ungkapan dan puisi tradisional digunakan untuk menyatakan suatu maksud (informasi) dari hasil aktivitas masyarakat Bugis di Pulau Lombok dengan nilai yang baik, buruk atau generik (netral). Karena bersifat universal dan etnis Bugis selalu mempertahankan adat-istiadatnya dimana pun mereka berada (bdk. Djajasudarma et al, 1977; Pelras, 2006), maka pappaseng dapat mencerminkan budaya Indonesia yang ada di Pulau Lombok dengan segala nilai budayanya. Akan tetapi, dalam tulisan ini, hanya akan ditelusuri nilai budaya yang berhubungan dengan waktu. Hal ini sekaligus akan menjawab apakah bentuk bahasa pappaseng masih dipertahankan seutuhnya dalam bahasa Bugis atau malah telah 
terkontaminasi di tengah kontak bahasa yang dialami di wilayah penutur bahasa pribumi (Sasak) yang dominan. Kekhasan inilah yang akan ditelusuri dalam beberapa bentuk pappaseng Bugis di Pulau Lombok.

\section{Pembahasan}

\subsection{Landasan Konseptual}

Tulisan ini mencoba mengkolaborasikan antara bahasa Bajo di Sumbawa dengan budayanya. Untuk itu, pengkolaborasiannya dimanifestasikan dalam sebuah pendekatan. Pendekatan itu merupakan penggabungan dua kajian (interdispliner), yakni linguistik dan antropologi, yang lebih dikenal dengan etnolinguitik. Adanya hubungan bahasa (linguistik) dan kebudayaan (antropologi) ini telah lama disadari oleh para ahli linguistik itu sendiri. Franz Boas, misalnya, adalah salah seorang yang sangat berkontribusi dalam pengembangan linguistik antropologi di Amerika, sehingga dijadikan sebagai pelopor linguistik antropologi di negara itu. Di Amerika itu sendiri, ilmu ini dinamakan antropologi linguistik (dengan variannya linguistik antropologi). Di Eropa dipakai istilah etnolinguistik (Duranti, 1997). Sebaliknya, di Indonesia ilmu ini disebut dengan linguistik budaya (Riana, 2003). Istilah yang dikemukakan oleh Riana tersebut sama dengan istilah linguistik antropologi (anthropological linguistics) yang dikemukakan oleh Foley (1997).

Pada dasarnya antropologi linguistik, linguistik antropologi, etnolinguistik, dan linguistik buduya secara umum memiliki kesamaan (Crystal, 1992:20; Duranti, 2001:1-2). Jika terdapat perbedaan, itu hanyalah masalah sudut pandang saja. Walaupun demikian, dalam tulisan ini akan disejajarkan dengan konsep Foley (1997) yang menggunakan istilah linguistik antropologi karena merupakan bagian dari linguistik. Jelasnya, Foley mengatakan bahwa linguistik antropologi adalah disiplin ilmu yang bersifat interpretatif yang lebih jauh mengupas bahasa untuk menemukan pemahaman budaya. Pandangan ini dipertegas lagi oleh Mbete (2004) bahwa linguistik kebudayaan sesungguhnya adalah bidang ilmu interdisipliner yang mengkaji hubungan kovariatif antara 
struktur bahasa dengan kebudayaan suatu masyarakat (lihat Ola, 2005). Melalui pendekatan linguistik antropologi, dapat dicermati apa yang dilakukan orang dengan bahasa dan ujaran-ujaran yang diproduksi; diam dan gestrus dihubungkan dengan konteks pemunculannya (Duranti, 200:9). Malinowski (Hymes, 1964:4) mengemukakan bahwa melalui etnolinguistik kita dapat menelusuri bagaimana bentuk-bentuk linguistik dipengaruhi oleh aspek budaya, sosial, mental, dan psikologis; apa hakikat sebenarnya dari bentuk dan makna serta bagaimana hubungan keduanya. Penggunaan bahasa dalam berkomunikasi cenderung dipandang sebagai fungsi kontrol atau suatu tindakan untuk saling memengaruhi partisipasi dalam suatu pertuturan (Hymes, 1964:5).

Etnolinguistik itu sendiri merupakan cabang linguistik yang bersifat makro yang kajiannya mencoba memahami bahasa dalam konteks sosial budaya. Kajian ini melihat fenomena bahasa bukan hanya sebagai fenomena bahasa semata, melainkan berkaitan juga dengan aspek-aspek budaya penuturnya. Oleh karena itu, kebudayaan beserta aspek-aspek penuturnya menjadi sebuah hal yang menarik untuk dikaji. Harapan yang timbul dalam suatu masyarakat, budaya tidak hanya bertahan pada satu generasi, akan tetapi dapat diwariskan kepada generasi berikutnya. Di sinilah peran bahasa, yakni sebagai sarana transfer kepada generasi berikutnya. Selain itu, bahasa juga digunakan sebagai alat pengembang budaya. Akan tetapi, pada dasarnya bahasa merupakan kebudayaan yang pertama dimiliki oleh setiap manusia dan bahasa itu dapat berkembang karena akal atau sistem pengetahuan manusia. Berdasarkan hal tersebut, dapat dilihat keterkaitan yang erat antara bahasa dan budaya (Sibarani, 2004: 9).

Hal yang paling mendasari hubungan bahasa dengan kebudayaan adalah bahasa harus dipelajari dalam konteks kebudayaan dan kebudayaan dapat dipelajari melalui bahasa (Sibarani, 2004: 49). Menurut Hymes (1964), antropologi linguistik adalah telaah tentang bahasa dalam konteks antropologi (the study of language within the context of antropology). Berdasarkan beberapa pengertian di atas, dapat dikatakan bahwa antara bahasa dan budaya mempunyai 
keterkaitan yang erat. Bahasa tidak hanya erat dengan budayanya, akan tetapi juga dengan penuturnya (masyarakat pemakai). Etnolinguistik merupakan cabang linguistik yang mempelajari variasi dan penggunaan bahasa dalam hubungannya dengan perkembangan waktu, perbedaan tempat, komunitas, sistem kekerabatan, pengaruh kebiasaan etnik, kepercayaan, etika berbahasa, dan adat istiadat dari pola-pola kebudayaan lain dari suatu suku bangsa (bdk. Sibarani, 2004 : 50).

Selanjutnya, Boas mengatakan bahwa bahasa merupakan manifestasi terpenting dari kehidupan mental penuturnya dan sebagai dasar pengklasifikasian pengalaman sehingga berbagai bahasa mengklasifikasikan secara berbeda dan tidak selalu disadari oleh penuturnya (Suhandano, 2004). Dengan kata lain, pengklasifikasian yang tampak pada sistem tata bahasa mencerminkan pikiran atau psikologi penuturnya. Pada mulanya, perhatian terhadap kaitan antara bahasa dan cara pandang dunia penuturnya lebih banyak dicurahkan pada masalah sistem tata bahasa (grammar), akan tetapi dalam menafsirkan pandangan dunia penutur juga dapat dilakukan dengan memeriksa kosakata (Suhandano, 2004). Hal ini sejalan dengan salah satu kontribusi Sapir (Oktavianus, 2006) yang sangat terkenal yaitu gagasannya yang menyatakan bahwa analisis terhadap kosakata suatu bahasa sangat penting untuk menguak lingkungan fisik dan sosial di mana penutur suatu bahasa bermukim dan hubungan antara kosakata dan nilai budaya bersifat multidireksional.

Sehubungan dengan adanya pertalian antara bahasa (kosakata) dan nilai budaya tersebut atau mengkaji bahasa melalui ungkapan tradisional Bugis (pappaseng) untuk melihat nilai budayanya maka akan ditelusuri konsep-konsep tentang nilai budaya itu sendiri. Hal ini dilakukan untuk memberikan asumsi dasar (pemahaman) tentang wujud dari nilai-nilai budaya secara universal, yang akhirnya nilai-nilai budaya apa saja yang ada dalam masyarakat Bugis dilihat dari petuah-petuah leluhurnya 
(pappaseng) secara kolektif. Untuk itu, perlu juga dibahas tentang batasan nilai terutama yang menyangkut nilai budaya.

Nilai dan nilai budaya itu sendiri dapat dipahami melalui pendapat para pakar di bidang tersebut. Definisi nilai yang diterima berbagai konsep yang diinginkan dalam ilmu sosial adalah hasil pengaruh seleksi perilaku (Kluckhon, 1951: 399). Pandangan ini dapat dibandingkan dengam paham yang menyatakan bahwa manusia tidak berbeda di dunia ini; semua tidak dapat berhenti hanya dengan sebuah pandangan (maksud) faktual dari pengalaman yang berlaku (lihat Kohler, 1938). Hasil pengaruh seleksi yang diungkapkan Kluckhon (1958) menunjukan bahwa manusia yang dikatakan Kohler (1938) tidak pernah terhenti dengan pengalaman yang berlaku dengan seleksi yang dianut melalui nilai-nilai yang berlaku bagi masyarakatnya sebagai makhluk sosial (Djajasudarma et al, 1997).

Konsep nilai yang digunakan dalam pamahaman tulisan ini menyangkut nilai baik-buruk dan netral yang berlaku bagi kehidupan berbudaya atas dasar pertimbangan petuah-petuah leluhur yang mengandung isi budaya baik pada zamannya maupun yang berlaku sekarang. Oleh karena itu, nilai budaya dalam hal ini dipahami sebagai nilai yang mengacu kepada berbagai hal (dengan pemahaman seluruh tingkah laku manusia sebagai hasil berbudaya), antara lain: nilai dapat mengacu pada minat, kesukaan, pilihan, tugas, kewajiban beragama, kebutuhan, keamanan, hasrat, keengganan, daya tarik, dan hal lain yang berhubungan dengan persamaan, yang melibatkan manusia dalam hubungan dengan manusia, dengan hidup dengan kerja, dengan waktu, dan dengan alam (Djajasudarma at al., 1997; Koentjaraningrat, 1996).

Berdasarkan hal tersebut, nilai dapat dipahami sebagai kesukaan atau pilihan yang melibatkan pertimbangan lima masalah dasar hidup 
yang menentukan orientasi nilai budaya manusia. Orientasi nilai dasar budaya itu akan diikuti orientasi nilai yang berhubungan dengan masalah dasar dalam kehidupan manusia. Lima masalah pokok kehidupan manusia berhubungan dengan orientasi nilai budaya, yang juga berhubungan dengan sistem nilai budaya dalam masyarakat. Orientasi nilai budaya secara universal berhubungan dengan sistem nilai budaya dalam masyarakat dan merupakan lima masalah pokok kehidupan manusia (lihat Koentjaraningrat. 1991: 3), yakni (1) hakikat hidup manusia (MH), (2) hakikat karya manusia (MK), (3) hakikat waktu manusia (MW), (4) hakikat alam manusia (MA), dan (5) hakikat hubungan manusia (MM). Dalam penelitian ini, kelima masalah pokok itu akan dipertimbangkan melalui pemahaman nilai budaya yang dipedomani dan yang netral (berlaku umum) dalam kehidupan masyarakat Bugis di Pulau Lombok. Selanjutnya, sistem nilai budaya adalah tingkat tertinggi dan paling abstrak dari adat istiadat. Hal ini disebabkan nilai budaya terdiri dari konsep-konsep mengenai segala sesuatu yang dinilai berharga dan penting oleh warga suatu masyarakat, sehingga dapat berfungsi sebagai suatu pedoman orientasi pada kehidupan para warga masyarakat yang bersangkutan (Koentjaraningrat, 1996).

Sistem nilai budaya merupakan nilai inti (core value) dari masyarakat. Nilai inti diikuti oleh setiap individu atau kelompok. Nilai itu biasanya dijunjung tinggi sehingga menjadi salah satu faktor penentu dalam berperilaku. Sistem nilai itu tidak tersebar secara sembarangan, tetapi mempunyai hubungan timbal balik, yang menjelaskan adanya tata tertib di dalam suatu masyarakat. Di dalam sistem nilai, biasanya terdapat berbagai konsep yang hidup dalam alam pikiran sebagian besar warga masyarakat mengenai hal-hal yang dianggap bernilai dalam hidup. Oleh 
karna itu, suatu sistem nilai budaya berfungsi sebagai pedoman tertinggi bagi kelakuan manusia (lihat Williams, 1960; Koentjaraningrat, 1981).

Sistem nilai budaya itu begitu kuat, meresap, dan berakar dalam jiwa masyarakat budaya sehingga sulit diganti dan/atau diubah dalam waktu yang singkat. Hal itu turut mendasari tulisan ini. Pemahaman tersebut dapat diamati melalui unsur bahasa yang disebut ungkapanungkapan tradisional Bugis yang berbentuk petuah-petuah leluhurnya (pappaseng).

Pappaseng itu sendiri adalah nasehat oleh leluhur yang berisi tata perilaku dalam budaya Bugis (petuah-petuah leluhur) (Pelras, 2006). Pappaseng ini merupakan salah satu bentuk ungkapan-ungkapan tradisional Bugis, di samping ada juga di dalamnya tentang pepatah, jampi (jappi) yang dilafalkan oleh para dukun (sanro) atau orang-orang yang dituakan pada saat diadakan upacara ritual, pengobatan, dan sebagainya (bandingkan dengan Pelras, 2006). Ungkapan itu sendiri adalah segala sesuatu yang diungkapkan berwujud gabungan kata dan maknanya tidak sama dengan pengadan setiap kata yang membentuk ungkapan itu (Djajasudarma et al., 1997).

Untuk mempermudah pemahaman, berikut akan digambarkan tentang kerangka pikir dalam penelitian ini.

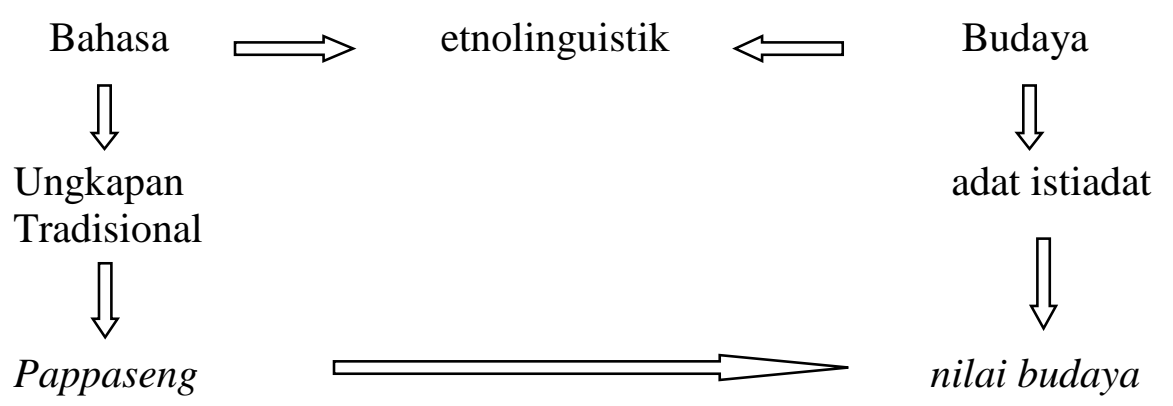


Berdasarkan pandangan di atas, dapat dikatakan bahwa untuk mengetahui nilai budaya masyarakat Bugis di Pulau Lombok khususnya yang berhubungan dengan hakikat karya dapat dilihat dari bahasanya. Bahasa yang dimaksud di sini berwujud tradisi lisan yang berupa petuahpetuah leluhurnya yang ada dalam kehidupan sehari-harinya. Dengan kata lain, nilai budaya tersebut lebih banyak ditunjukkan di samping oleh sistem tata bahasanya, juga dapat dilihat dari kosakatanya (leksikon) sebagai unsur pembentuk pappaseng tersebut baik yang implisit maupun tecit.

\subsection{Nilai Budaya yang Berhubungan dengan Waktu dalam Petuah}

\section{Leluhur Bugis}

Penelitian ini mencoba melihat fenomena budaya berdasarkan bahasanya. Fenomena budaya yang dimaksud adalah merujuk pada sistem nilainya khusunya yang berhubungan dengan waktu dalam hidup masyarakatnya. Sebaliknya, bahasanya merujuk pada ungkapan tradisional yang berupa pappaseng yang dibentuknya. Dalam penelitian ini, pappaseng yang dibentuk oleh bahasa dan budaya sebagai sasaran pemahamannya yang dijadikan objeknya itu berasal dari satu etnis pendatang di Pulau Lombok saja. Etnis pendatang yang dimaksud adalah Bugis.

Ungkapan tradisional memiliki makna (informasi) yang mengandung nilai budaya. Nilai budaya dalam hal ini dipahami sebagai nilai yang mengacu kepada berbagai hal (dengan pemahaman seluruh tingkah laku manusia sebagai hasil berbudaya), antara lain nilai yang mengacu pada minat, kesukaan, pilihan, tugas, kewajiban beragama, kebutuhan, keamanan, hasrat, keengganan, daya tarik, dan hal lain yang berhubungan dengan perasaan, yang melibatkan manusia dalam 
hubungannya dengan manusia (MM), dengan hidup ( $\mathrm{MH})$, dengan kerja (MK), dengan waktu (MW), dan dengan alam (MA) (lihat Djajasudarma, 1997).

Hubungan manusia dengan berbagai hal tersebut merupakan orientasi nilai budaya secara universal dan sekaligus termasuk dalam lima masalah pokok kehidupan manusia (Koentjaraningrat, 1981), yaitu (1) hakikat hidup manusia (MH), (2) hakikat karya manusia (KM), (3) hakikat waktu manuisa (MW), (4) hakikat alam manusia (MA), dan (5) hakikat hubungan manusia (MM). Akan tetapi, dalam ungkapan tradisional Bugis tidak semua orientasi nilai budaya atau lima masalah pokok hidup manusia ada. Orientasi nilai budaya yang muncul hanya beberapa saja tergantung pada data ungkapan yang ditemukan pada etnis tersebut.

Pappaseng adalah ungkapan tradisional Bugis yang mengandung nasehat. Ungkapan tradisional ini selalu dipedomani oleh setiap warganya. Hal ini menjadi parameter dalam melihat setiap ungkapan yang ada. Nilai budaya dalam ungkapan berdasarkan data yang terjaring dapat dipilih menurut makna (informasi)-nya. Artinya, hubungan manusia dengan waktu dapat ditelusuri pada korpus tulisan ini.

Hubungan manusia dengan waktu terdapat pada tiga bentuk pappaseng. Pappaseng yang merujuk pada hubungan itu hanya dibentuk dengan kalimat deklaratif. Hubungan manusia dengan waktu ini memuat nilai yang mengacu pada waktu sekarang dan masa yang akan datang. Pappaseng yang merujuk pada hubungan manusia dengan waktu itu adalah data (1), (2), dan (3) berikut ini.

(1) Engkana sihettu matu makkunraie laoki ruane 'ada suatu waktu nanti perempuan mendatangi laki-laki' 'Ada suatu waktu nanti perempuan mendatangi laki-laki' 
(2) Engkasi hettu matu maega kunraie $n a$ ruane 'Ada suatu waktu nanti banyak perempuan daripada laki-laki' 'Ada suatu waktu nanti banyak perempuan daripada laki-laki'

(3) Engkasi hettu matu meongge sibawa asue siannreng 'Ada suatu waktu nanti kucing dengan anjing satu tempat makan'

'Ada suatu waktu nanti kucing dengan anjing satu tempat makan’

Data pappaseng di atas memperlihatkan bahwa orang Bugis juga mengenal sistem waktu. Waktu itu diungkapan dengan adanya frase si hettu 'suatu waktu' sebagai bagian kalimat dari setiap data di atas. Frase si hettu 'suatu waktu' artinya ada satu masa. Adanya frase si hettu 'suatu waktu' ini secara tidak langsung di dalamnya ada yang dinamakan dengan waktu dulu, kini, atau depan. Apabila frase ini digabungkan dengan bagian kalimat lain, engka si hettu matu 'ada satu waktu nanti' menunjukkan bahwa orang Bugis juga meyakini adanya suatu masa akan datang. Ini berarti bukan saja waktu sekarang yang ada dalam dunianya, namun orang Bugis juga selalu memperhitungkan waktu yang akan datang sebagai kelanjutan dari waktu kini.

Adanya sistem waktu dulu, sekarang, dan akan datang itu sebagai patokan bagi orang Bugis untuk melakukan perubahan-perubahan yang ada dalam budayanya. Perubahan-perubahan itu tampak pada data-data pappaseng di atas. Data (1) menggambarkan tentang suatu waktu nanti perempuan yang akan mendatangi laki-laki. Data ini secara tidak langsung dijelaskan bahwa pada saat sekarang yang bertindak sebagai pelaku dalam predikat "mendatangi" adalah laki-laki bukan perempuan. Dalam budaya Bugis dulu, perempuan yang masih gadis hanya diam di rumah dan menunggu dilamar oleh pihak laki-laki. Pihak laki-laki yang datang melamar itu pun harus berasal dari keluarga sendiri. Artinya, pada masa dulu tidak diperkenankan pihak perempuan dan laki-laki untuk 
memadu kasih, namun pada masanya kedua belah pihak itu akan dinikahkan oleh keluarganya sendiri. Akan tetapi, orang Bugis meyakini bahwa suatu masa nanti itu akan berubah.

Pada masa sekarang ini saja, budaya yang tidak mengenal cinta kasih sesama lain jenis dan hanya langsung menikah itu sudah tidak berlaku lagi. Pihak muda-mudi sudah mulai mencari pasangan hidup masing-masing. Hal itu terbukti dari banyaknya muda-mudi yang telah menikah dengan orang yang bukan berasal dari keluarga sendiri melainkan dari keluarga lain hasil dari cinta kasih mereka. Sebagian besar mereka sudah saling mengunjungi. Pihak perempuan sudah tidak tabu lagi untuk mendatangi pihak laki-laki. Ini berarti, adanya perubahan peran dari penerima sebagai pelaku, yang dulu mendatangi, suatu saat akan berubah menjadi didatangi. Dilihat dari adanya pappaseng (1) itu secara otomatis perubahan ini tetap ada dalam budaya Bugis sepanjang masih dalam taraf siri-nya 'budaya malunya'.

Fenomena tersebut dipertegas dengan adanya bagian kalimat maega kunrai na ruane 'banyak perempuan daripada laki-laki' pada data (2). Data tersebut menggambarkan bahwa suatu masa nanti tidak lagi pihak laki-laki yang lebih banyak daripada perempuan, namun sebaliknya perempuanlah yang lebih banyak daripada laki-laki. Perubahan ini tidak saja dilihat dari sistem jenis kelamin saja, namun peran dalam berbagai aspek itu sebagai pelakunya adalah perempuan. Pada masa Bugis dahulu, sebagian besar wanitanya hanya berperan sebagai pengurus rumah tangga dan tidak diperbolehkan ikut beraktivitas sebagai pencari nafkah. Dalam budaya itu, yang lebih dominan mencari nafkah hanya pihak laki-laki saja. Pada saat sekarang, aktivitas itu bukan lagi didominasi oleh pihak laki-laki, namun pihak perempuan juga sudah mulai ikut berperan. Hal 
ini didasarkan oleh perubahan itu yang menuntut perempuan harus bisa mengimbangi aktivitas laki-laki.

Lain halnya dengan pappaseng (3) yang lebih melihat perubahan waktu itu dalam hal yang positif. Maksudnya, dalam tulisan ini, lebih ditekankan pada perubahan dari hal-hal negatif pada fase dulu akan menjadi hal-hal yang positif pada fase sekarang atau masa akan datang. Dalam budaya Bugis, perubahan itu digambarkan melalui hubungan keseharian meong 'kucing' dan asu 'anjing'. Dalam budaya Bugis dulu, kucing dan anjing dikenal sebagai dua binatang yang selalu bermusuhan. Anjing dan kucing tidak bisa bertemu dalam kondisi apapun karena secara spontan binatang-binatang itu langsung melakukan perang. Akan tetapi, orang Bugis juga mempunyai keyakinan melalui pappaseng (3) yang berbentuk kalimat deklaratif, engka si hettu matu meongnge siandreng silong asue 'ada suatu waktu nanti kucing satu tempat makan dengan anjing'. Pappaseng ini mengisyaratkan bahwa anjing dan kucing tidak selamanya bermusuhan, namun ada masanya nanti kedua binatang itu akan bersahabat. Karena telah bersahabat maka kemungkinan nantinya akan makan bersama dalam satu tempat. Hal ini menunjukkan bahwa tidak selamanya hal-hal yang negatif yang berupa permusuhan itu akan berlangsung, namun ada masanya nanti akan menjadi positif, dalam hal ini kebersamaan dan ketentraman. Hal ini sebagai gambaran yang dipedomani oleh orang Bugis yang merujuk pada penyimpulan umum bahwa segala perbuatan negatif agar segera disadari baik dari perbuatan sendiri maupun orang lain untuk merujuk pada kehidupan yang positif, tentram dan damai dalam setiap kebersamaan.

Untuk itu, pappaseng di atas mengisyaratkan secara umum bahwa waktu itu pada kenyataannya tidak statis tetapi selalu berubah dan perubahan ini dapat berupa pergantian peran, aktivitas, atau bahkan hasil 
dan kenyataan yang ada. Perubahan itu diharapkan selalu menjadi yang positif dalam kehidupan sehari-hari agar menjadi yang lebih baik sehingga tetap menghargai waktu-waktu yang ada dalam dunianya.

Untuk memudahkan pemahaman deskripsi nilai budaya yang berhubungan dengan waktu yang tercermin dalam petuah-petuah leluhur Bugis, pappaseng, dapat digambarkan dalam bentuk bagan berikut.

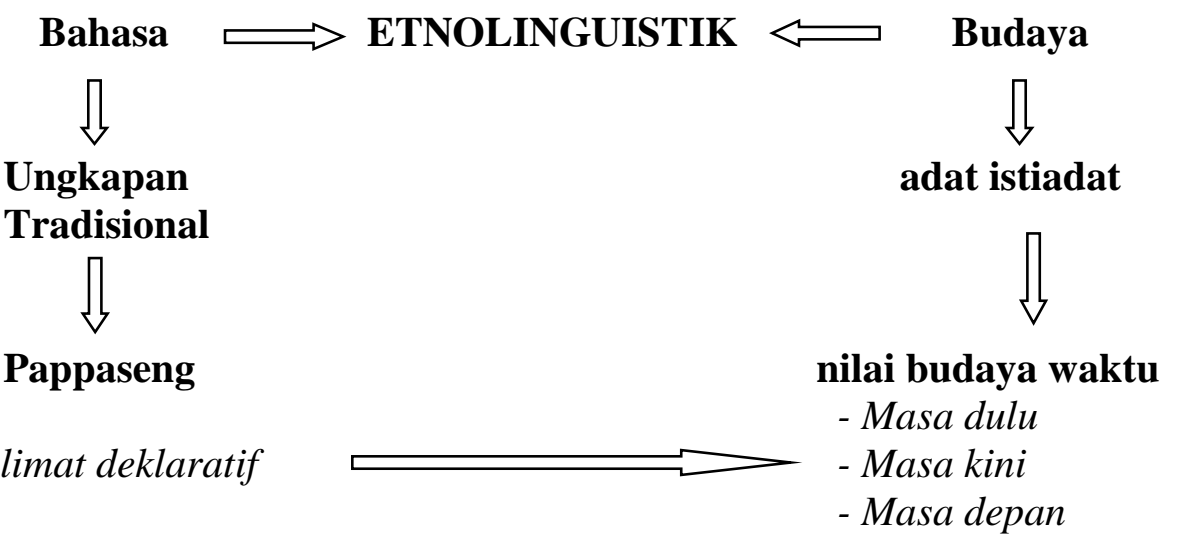

\section{Penutup}

Etnis Bugis ditemukan di jazirah Sulawesi Selatan sebagai daerah asalnya. Etnis ini dikenal sebagai etnis pengembara sehingga dapat ditemukan di berbagai wilayah pantai Nusantara. Penentuan pemukiman di pesisir pantai itu dan pada sebagian besar di berbagai wilayah pesisir pulau lainnya itu didasarkan pada kenyataan bahwa sebagian besar orang Bugis bermatapencaharian sebagai pelaut. Berprofesi sebagai pelaut bukan hal mudah karena terdapat berbagai tantangan. Untuk itu, orang Bugis selalu memperhatikan waktu. Waktu ini diatur dalam pappasengnya. Waktu dalam budaya Bugis diyakini secara tidak statis. Waktu selalu berubah dan perubahan ini dapat berupa pergantian peran, aktivitas, atau bahkan hasil dan kenyataan yang ada. Perubahan itu diharapkan selalu menjadi yang positif dalam kehidupan sehari-hari agar menjadi yang lebih baik sehingga tetap menghargai waktu-waktu yang 
ada dalam dunianya. Nilai ini selalu dipedomani oleh masyarakatnya untuk merealisasikan harapan menjadi keberhasilan dalam hidupnya sehari-hari sehingga dapat bertahan hidup di tengah hegemoni kemayoritasan etnis pribumi.

\section{Daftar Pustaka}

Casson, R.W. 1981. Language, Culture, and Cognition. London: Mac. Millan.

Chaer, Abdul dan Leoni Agustina. 1995. Sosiolinguistik: Perkenalan Awal. Jakarta: Rineka Cipta.

Crystal, D. 1987. The Cambridge Encyclopedia of Language. Cambridge: Cambridge University Press.

Dardjowidjodjo, Soenjono. 2005. Psikolinguistik: Pengantar Pemahaman Bahasa Manusia. Jakarta: Yayasan Obor Indonesia.

Djajasudarma, T.F., et al. 1997. Nilai Budaya dalam Ungkapan dan Peribahasa Sunda. Jakarta: Pusat Pembinaan dan Pengembangan Bahasa, Depdikbud.

Duranti, A. 1997. Linguistic Anthropology. Cambridge: Cambridge University Press.

Foley, W. A. 1997. Anthropological Linguistics: An Introduction. Oxford: Blackwell Publishers.

Frake, C.O. 1972. "The Ethnographic Study of Cognitive Systems". Dalam J.A. Fishman (ed). Readings in the Sociology of Language. The Hague - Paris: Mouton.

Greenberg, J. 1964. “Anthropological Linguistics”. An Introduction: 317. 
Halliday, M.A.K. 1985. Spoken and Written Language. Victoria: Deakin University Press.

Humboldt, Wilhelm. 1971. Linguistic Variabiloity \& Intelectual Development. Terjemahan: George C. Buck dan Frithjof A. Raven. Philadelphia: University of Pensylvania Press.

Istiyani, Chatarina Pancer. 2004. Tubuh \& Bahasa: Aspek-aspek Linguistik Pengungkapan Pandangan Masyarakat Lewolema terhadap Kesehatan. Yogyakarta: Galang Press.

Kluckhon, Clyde. 1951. "Values and Value-Orientations in the Theory of Action: An Explanation in Definition and Classification", 388-433. Dalam Talcott Persons and Edward Shills (eds.) 'Toward a General Theory of Actions'. Cambridge: Harvard University Press.

Koentjaraningrat. 1974. Pengantar Ilmu Antropologi. Jakarta: Angkasa Baru.

1996. Pengantar Antropologi I. Jakarta: Rineka Cipta.

Kramsch, C. 1998. Language and Culture. Oxford: Oxford University Press.

Machmud, Andi Bau Hasan. 1976. Silasa-silasa: Setetes Embun di Tanah Gersang. Ujung Pandang: Bhakti Centra Baru.

Masinambow. 1998. “ Hubungan Timbal Balik antara Bahasa dan Kebudayaan". Makalah pada Pertemuan Pra-kuliah Program Studi Masalah Linguistik dan Kajian Budaya Universitas Udayana Denpasar, Tahun Akademik 1998/1999, 20-24 Juli.

Mattulada. 1974. "Bugis-Makassar: Manusi dan Kebudayaan". Berita Antropologi, Jakarta, 16 (Edisi Khusus).

Mbete, A. M. 2004. "Linguistik Kebudayaan: Rintisan Konsep dan Beberapa Aspek Kajiannya". Dalam Bawa, I. W. Dan Cika, I. W. (ed.). Bahasa dalam Perspektif Kebudayaan. Hal. 16-32. Denpasar: Penerbit Universitas Udayana. 
Oktavianus. 2006. "Nilai Budaya dalam Ungkapan Minangkabau: Sebuah Kajian dari Perspektif Antropologi Linguistik". Linguistik Indonesia, Tahun ke 24, No. 1, Februari 2006.

Ola, S. S. 2005. "Tuturan Ritual dalam Konteks Perubahan Budaya Kelompok Etnik Lamaholot di Pulau Adanora, Flores Timur". Disertasi. Denpasar: Program Pascasarjana Universitas Udayana.

Palmer, G. B. 1996. Toward a Theory of Cultural Linguistics. Austin: University of Texas Press.

Papper, Stephen. 1958. The Sources of Value. Berkeley: University of California Press.

Pateda, M. 1990. Aspek-aspek Psikolinguistik. Flores: Nusa Indah.

Pelras, Christian, 2006. The Bugis. Diterjemahkan oleh Abdul Rahman Abu at al. dengan judul "Manusia Bugis". Jakarta: Ecole Francaise d'Extreme-Orient.

Riana, I. K. 2003. "Linguistik Budaya: Kedudukan dan Ranah Pengkajiannya". Pidato Pengukuhan sebagai Guru Besar Tetap dalam Bidang Ilmu Linguistik Budaya Universitas Udayana. Denpasar: Universitas Udayana.

Robin, R.H. 1992. Linguistik Umum: Sebuah Pengantar. Diterjemahkan oleh Soenarjati Djajanegara dari judul asli: General Linguistics. Yogyakarta: Penerbit Kanisius.

Sapir, Edward. 1970. Longuage: An Introduction to the Study of Speech. London: A Harvest Book.

Saussure, Ferdinand de. 1973. Cours de Linguistique Generale. Diterjemahkan oleh Rahayu S. Hidayat 'Pengantar Lingusitik Umum. Yogyakarta: Gadjah Mada University Press.

Silzer, Peter J. 1990. "Bahasa dan Kebudayaan: Anak Kembar Siam”. Linguistik Indonesia, Th. I. 1:1-11.

Spradley, J.P. 1980. Participant Observation. New York: Holt, Rinehart, and Winston. 
. 1997. The Etnographic Interview. Diterjemahkan oleh Misbah Zulfa Elizabeth dengan judul Metode Etnografi. Yogyakarta: Tiara Wacana Jogja.

Suhandano. 2004. "Klasifikasi Tumbuh-tumbuhan dalam Bahasa Jawa: Sebuah Kajian Linguistik Antropologi". Disertasi. Yogyakarta: Program Pascasarjana Universitas Gadjah Mada. 